\title{
ANIBACTERIAL, ANTIBIOFILM AND ANTIOXIDANT ACTIVITY OF Potamogeton nodosus Poir. EXTRACTS
}

\author{
Jelena Đurđević*, Sava Vasić, Ivana Radojević, Gorica Đelić and Ljiljana Čomić \\ Department of Biology and Ecology, Faculty of Science, University of Kragujevac, \\ Radoja Domanovića 12, 34000 Kragujevac, Republic of Serbia \\ *Corresponding author, e-mail: jelena.djurdjevic@yahoo.com
}

(Received April 2, 2014)

\begin{abstract}
Antibacterial, antibiofilm and antioxidant activity of acetone, ethanol, ethyl acetate and diethyl ether extracts of $P$. nodosus Poir. were tested.

In vitro antibacterial activity was investigated by microdilution method. Minimum inhibitory concentration (MIC) and minimum bactericidal concentration (MBC) have been determined. The values were in the range from 5 to $>5 \mathrm{mg} / \mathrm{ml}$.

Antibiofilm activity was tested by crystal violet assay. The biofilm inhibitory concentration (BIC) values were from 2.03 to $>10 \mathrm{mg} / \mathrm{ml}$. The best results against biofilm formation had ethanol and ethyl acetate extracts.

The total phenolic content was established by using Folin-Ciocalteu method. The highest total phenol content was found in the ethyl acetate extract $(28.45 \mathrm{mg} \mathrm{GA} / \mathrm{g})$ while the lowest content in the ethanol extract $(22.74 \mathrm{mg} \mathrm{GA} / \mathrm{g})$. The concentrations of flavonoids were determined using aluminium chloride method. The concentration of total flavonoid content was $102.09 \mathrm{mg} \mathrm{RU} / \mathrm{g}$ for the ethyl acetate extract, while the lowest content was noticed in diethyl ether extract (32.93 $\mathrm{mg} \mathrm{RU} / \mathrm{g})$.

The antioxidant activity was determined by the DPPH free radicals assay. Antioxidative efficiency was in the range from 641.77 to $8811.63 \mu \mathrm{g} / \mathrm{ml}$. The tested extracts showed weak antioxidant activity $(\mathrm{AAI}<0.5)$.
\end{abstract}

Keywords: Potamogeton nodosus, phenolics, flavonoids, DPPH, antibacterial activity, biofilm.

\section{INTRODUCTION}

Longleaf pondweed (Potamogeton nodosus Poir., fam. Potamogetonaceae) is a species of aquatic plants. Longleaf pondweed has two different kinds of leaves. The submerged (underwater) leaves are long and thin, growing up to $50 \mathrm{~cm}$ long. The floating leaves are oval shaped and grow up to $12 \mathrm{~cm}$ long. It is widely distributed in continental and subtropical zones of both hemispheres (Europe, Asia, North America and Africa) (JOSIFOVIĆ et al., 1975).

Pseudomonas aeruginosa is a common bacteria that can cause disease not only in animals but also in humans. The symptoms of such infections are generalized inflammation and sepsis. If such colonizations occur in critical body organs, such as the lungs, the urinary tract, and kidneys, the results can be fatal. They often cannot be treated effectively with traditional antibiotic therapy, because of resistance to antibiotics. 
Acetone, ethanol, ethyl acetate and diethyl ether extracts of $P$. nodosus were tested. These solvents were chosen due to their different polarity, and therefore the various possibilities of the secondary metabolites to dissolve. This analysis was first done on this plant extracts.

Biological activities of the $P$. nodosushaven't been sufficiently researched. Previous chemical investigations on different species of Potamogeton have shown the presence of alkaloids, flavonoids, and a labdane diterpenoid (QAIS et al., 1998; RAMESH et al, 2014).

The objective of this study was to evaluate antibacterial activity of ethanol, ethyl acetate, acetone, diethyl ether extracts of $P$. nodosus, as well as the effect of these extracts on biofilm formation against Pseudomonas aeruginosa ATCC 27853 and Pseudomonas aeruginosa. Also the aim of this study was the determination of total phenolic content, flavonoid content and antioxidant activity by DPPH radicals scavenging capacity assay.

\section{MATERIALS AND METHODS}

\section{Chemicals}

Organic solvents (methanol, ethanol, ethyl acetate, acetone, diethyl ether) were purchased from Zorka Pharma (Šabac, Serbia). 2,2-diphenyl-1-picrylhydrazyl (DPPH), ascorbic acid and Folin-Ciocalteu phenol reagent were obtained from Sigma Chemicals Co. (St. Louis, MO, USA). Gallic acid, rutin hydrate and aluminium chloride hexahydrate $\left(\mathrm{AlCl}_{3} \times 6 \mathrm{H}_{2} \mathrm{O}\right)$ were purchased from Acros Organics (New Jersey, USA). Sodium carbonate $\left(\mathrm{Na}_{2} \mathrm{CO}_{3}\right)$ was obtained from MPHemija (Belgrade, Serbia). Dimethyl sulfoxide (DMSO) was purchased from Centrohem (Stara Pazova, Serbia). Resazurin was obtained from Alfa Aesar GmbH \& Co. (KG, Karlsruhe, Germany). Nutrient agar and Mueller-Hinton broth were purchased from Liofilchem (Italy). Doxycycline was from Galenika A.D. (Belgrade, Serbia) and crystal violet stain was from Fluka AG (Buchs, Switzerland).

\section{Plant materials}

P. nodosus was collected in April 2013, from the region of Ovčar-Kablar Gorge, in the western Serbia, part of the composite valley of the West Morava River. Identification and classification of the plant material was performed at the Faculty of Science, University of Belgrade. Voucher specimens (16756) are deposited in Herbarium of the Institute of Botany and Botanical garden "Jevremovac", University of Belgrade (BEOU) (Thiers 2013). The collected plant material (stems and leaves) was air-dried in darkness at ambient temperature $\left(20^{\circ} \mathrm{C}\right)$. The dried plant material was cut up and stored in paper bags until needed.

\section{Preparation of plant extracts}

Dried, ground plant material was extracted by maceration with acetone, ethanol, ethyl acetate and diethyl ether. Briefly, $50 \mathrm{~g}$ of plant material was soaked with $250 \mathrm{ml}$ of solvent. The plant material was macerated three times at room temperature using fresh solvent every $24 \mathrm{~h}$. The filtrates obtained were combined and then evaporated to dryness using a rotary evaporator at $40^{\circ} \mathrm{C}$. The amounts of crude extracts obtained from P. nodosus are presented in Table 1 . The obtained extracts were kept in sterile sample tubes and stored at $4^{\circ} \mathrm{C}$.

\section{Determination of total phenolic content}

The total phenolic content was determined using Folin-Ciocalteu method (WoOTTONBEARD et al., 2011). The reaction mixture was prepared by mixing $0.2 \mathrm{ml}$ of methanolic solution of extracts $(1 \mathrm{mg} / \mathrm{ml})$ and $1.5 \mathrm{ml}$ of $10 \%$ Folin-Ciocalteu reagent dissolved in water. The mixture 
was allowed to equilibrate for $5 \mathrm{~min}$ and then it was mixed with $1.5 \mathrm{ml} 6 \% \mathrm{Na}_{2} \mathrm{CO}_{3}$ solution. After being in incubation for $90 \mathrm{~min}$ at room temperature and in darkness, the absorbance of the mixture was read at $725 \mathrm{~nm}$ against a blank using spectrophotometer. The blank was prepared with methanol instead of extract solution. The samples were prepared in triplicate and the mean value of absorbance was obtained. The same procedure was repeated for gallic acid which was used for calibration of standard curve. Total phenol content is reported as gallic acid equivalent by reference to linear equation of the standard curve. Then the total phenolic content was expressed as milligram of gallic acid equivalent per gram of extract (mg GAE/g of extract).

\section{Determination of total flavonoid content}

The concentrations of flavonoids were established by using aluminium chloride method (QUETTIER-DELEU et al., 2000). The mixture contained $2 \mathrm{ml}$ of methanolic solution of extract (1 $\mathrm{mg} / \mathrm{ml}$ ) and $2 \mathrm{ml}$ of $2 \%$ methanolic $\mathrm{AlCl}_{3} \times 6 \mathrm{H}_{2} \mathrm{O}$ solution. The mixture was vigorously shaken, and after $10 \mathrm{~min}$ of incubation at room temperature, the absorbance versus a prepared blank was read at $430 \mathrm{~nm}$ using spectrophotometer. The samples were prepared in triplicate and the mean value of absorbance was obtained. Rutin was used as a standard for calibration of standard curve. The concentrations of flavonoids were calculated from the linear equation of standard curve. Then the concentrations of flavonoids were expressed as milligram of rutin equivalent per gram of extract (mg of RUE/g of extract).

\section{DPPH radicals scavenging capacity assay}

The ability of the plant extract to scavenge 2,2-diphenyl-1-picrylhydrazyl (DPPH) free radicals was assessed (TAKAO et al. 1994), along with antioxidant activity index (AAI) (SCHERER and GODOY, 2009). The stock solution of the plant extracts was prepared in methanol to achieve the concentration of $2000 \mathrm{mg} / \mathrm{ml}$. Further, two-fold dilutions were made to obtain concentrations from $1000 \mathrm{mg} / \mathrm{ml}$ to $15.6 \mathrm{mg} / \mathrm{ml}$. Diluted solutions of extract $(2 \mathrm{ml}$ each) were mixed with $2 \mathrm{ml}$ of DPPH methanolic solution $(80 \mu \mathrm{g} / \mathrm{ml})$. After $30 \mathrm{~min}$ in darkness at room temperature, the absorbance was read in a spectrophotometer at $517 \mathrm{~nm}$. The control samples consisted of $2 \mathrm{ml}$ of methanol added to $2 \mathrm{ml}$ of DPPH solution. Ascorbic acid was used as a positive control. The experiment was performed in triplicate. Scavenging activity is expressed as the inhibition percentage calculated using the following equation:

Scavenging activity $\left.(\%)=100 \times\left[\left(\mathrm{A}_{\text {control }}-\mathrm{A}_{\text {sample }}\right) / \mathrm{A}_{\text {control }}\right)\right]$

where $\mathrm{A}_{\text {control }}$ is the absorbance of the control and $\mathrm{A}_{\text {sample }}$ is the absorbance of the extract. The $\mathrm{IC}_{50}$ value is the effective concentration at which $50 \%$ of DPPH radicals were scavenged. It was obtained from the graph of scavenging activity $(\%)$ versus concentration of samples. Low $\mathrm{IC}_{50}$ value indicates strong ability of the extract to act as DPPH scavenger. The antioxidant activity was expressed as the antioxidant activity index (AAI), calculated using the following equation:

$\mathrm{AAI}=$ final concentration of DPPH $(\mu \mathrm{g} / \mathrm{ml}) / \mathrm{IC}_{50}(\mu \mathrm{g} / \mathrm{ml})$

The estimation of AAI was: if $\mathrm{AAI}<0.5$ - poor antioxidant activity; $\mathrm{AAI}>0.5-1$ - moderate antioxidant activity; AAI $>1-2$ - strong antioxidant activity and AAI $>2$ - very strong antioxidant activity.

\section{Test bacteria}

Two bacterial strains have been tested. The clinical isolate, Pseudomonas aeruginosa was a generous gift from the Institute of Public Health, Kragujevac. The bacterium P. aeruginosa 
ATCC 27853 was provided from a collection held by the Laboratory of Microbiology, Faculty of Science, University of Kragujevac.

\section{Antibacterial assay}

Antibacterial activity was tested by determining the minimum inhibitory concentration (MIC) and minimum bactericidal concentration (MBC) using microdilution method with resazurin (SARKER et al., 2007). Bacterial suspensions were prepared by direct colony method. The turbidity of initial suspension was adjusted by comparing it with 0.5 McFarland's standard on densitometer. Initial bacterial suspensions contain about $10^{8}$ colony forming units $(\mathrm{CFU}) / \mathrm{ml}$ and then 1:100 when diluted in sterile $0.85 \%$ saline. Twofold serial dilutions of plant extract were made in a concentration range from $5 \mathrm{mg} / \mathrm{ml}$ to $0.0195 \mathrm{mg} / \mathrm{ml}$ in sterile 96 -well plates containing Mueller-Hinton broth. A $10 \mu \mathrm{l}$ of diluted bacterial suspension was added to each well to give a final concentration of $5 \times 10^{5} \mathrm{CFU} / \mathrm{ml}$. Finally, $10 \mu \mathrm{l}$ of resazurin solution, as an indicator of microbial growth, was added to each well. The inoculated plates were incubated at $37^{\circ} \mathrm{C}$ for $24 \mathrm{~h}$. MIC was defined as the lowest concentration of tested compounds that prevented resazurin color change from blue to pink. MBC was determined by plating $10 \mu \mathrm{l}$ of samples from wells, where no indicator of color change was recorded, on nutrient agar. At the end of the incubation period the lowest concentration with no growth (no colony) was defined as minimum bactericidal concentration.

Doxycycline, dissolved in nutrient liquid medium was used as positive control. Solvent control test was performed in order to study an effect of $10 \%$ DMSO on the growth of bacteria. It was observed that $10 \%$ DMSO did not inhibit the growth of bacteria. Each test included growth control and sterility control. All tests were performed in duplicate and MICs were constant.

\section{Biofilm formation assay and quantification}

The ability of bacteria to form biofilms was assayed as described by O'ToOLE and KOLTER (1998) with some modifications. In sterile 96-well tissue culture plates (Sarstedt, Germany) containing $50 \mu \mathrm{l}$ of Mueller-Hinton broth per well, a $50 \mu \mathrm{l}$ of fresh bacterial suspension (1.0 McFarland) was added. After incubation at $37^{\circ} \mathrm{C}$ for $48 \mathrm{~h}$, the content of each well was gently removed by tapping the plates. The wells were washed with $200 \mu 1$ of sterile saline to remove free-floating bacteria. Biofilms formed by adherent cells in plate were stained with $0.1 \%$ crystal violet and incubated at the room temperature for $20 \mathrm{~min}$. Excess stain was rinsed off by thorough washing with deionized water and plates were fixed with $200 \mu$ of $96 \%$ ethanol. Optical densities (OD) of stained adherent bacteria were measured at $630 \mathrm{~nm}$ using an ELISA microplate reader. The cut-off optical density (ODc) was defined as three standard deviations above the mean OD of the negative control (culture medium). Strains were classified as follows: $\mathrm{OD} \leq \mathrm{ODc}$ no biofilm producer, $\mathrm{ODc}<\mathrm{OD} \leq 2 \times$ ODc weak biofilm producer, $2 \times$ ODc $<$ OD $\leq 4 \times$ ODc moderate biofilm producer and $4 \times$ ODc $<$ OD strong biofilm producer (STEPANOVIĆ et al., 2000).

\section{Effect on biofilm formation}

A modified crystal violet assay was employed to test the effect of plant extracts on biofilm formation. Twofold serial dilutions of plant extract were made in sterile 96-well tissue culture plates containing $50 \mu \mathrm{l}$ of Mueller-Hinton broth per well. The tested concentration range was from $10 \mathrm{mg} / \mathrm{ml}$ to $0.039 \mathrm{mg} / \mathrm{ml}$. A $50 \mu \mathrm{l}$ of fresh bacterial suspension (1.0 McFarland) was added to each well. Growth control (cells + broth), media control (only broth) and blank control (broth + extract) were included. After being in incubation at $37^{\circ} \mathrm{C}$ for $48 \mathrm{~h}$, the biofilm biomass was assayed using the crystal violet staining assay as described above. The percentage of biofilm inhibition was calculated using the following formula: [(OD growth control - OD sample) / OD growth control] $\times 100$. The biofilm inhibition concentration $\left(\mathrm{BIC}_{50}\right)$ was defined as the lowest 
concentration of extract that showed $50 \%$ inhibition on the biofilm formation (CHAIEB et al., 2011).

\section{RESULTS AND DISCUSSION}

\section{Total phenol and flavonoid content in plant extracts}

Total phenol and flavonoid content was determined in acetone, ethanol, ethyl acetate and diethyl ether extract of $P$. nodosus. Various solvents were used in order to achieve extraction of active substances with diversity in their polarity. The content of phenolic compounds was measured spectrophotometrically by using method with Folin-Ciocalteu reagent for phenols and method with aluminium chloride for flavonoids. The results are presented in Table 1. The highest total phenol content was found in the ethyl acetate extract $(28.45 \mathrm{mg} \mathrm{GA} / \mathrm{g})$ while the lowest content was in the ethanol extract $(22.74 \mathrm{mg} \mathrm{GA} / \mathrm{g})$, and the similar case was with the total flavonoid content, up to $102.09 \mathrm{mg} \mathrm{RU} / \mathrm{g}$ for the ethyl acetate extract, while the lowest content was noticed in diethyl ether extract (32.93 $\mathrm{mg} \mathrm{RU} / \mathrm{g})$. Genus Potamogeton was manifested by different flavonoid glycoside distributions between floating and submersed foliage of morphologically heterophyllous species and according to LES and SHERIDAN (1990) it had been reported for the first time.

Table 1. Yield, content of total phenolic and flavonoid content in the extracts of Potamogeton nodosus.

\begin{tabular}{|c|c|c|c|}
\hline Type of extract & $\begin{array}{c}\text { Yield } \\
(\mathrm{g} / 50 \mathrm{~g} \mathrm{dw})\end{array}$ & $\begin{array}{c}\text { Total phenolic } \\
\text { content }^{1} \\
\text { (mg GA/g of extract) }\end{array}$ & $\begin{array}{l}\text { Flavonoid content }^{1} \\
\text { (mgRU /g of extract) }\end{array}$ \\
\hline Ethanol & 2.78 & $22.74 \pm 0.12$ & $47.96 \pm 0.10$ \\
\hline Acetone & 1.32 & $24.20 \pm 2.28$ & $69.10 \pm 0.19$ \\
\hline Ethyl acetate & 1.24 & $28.45 \pm 0.19$ & $102.09 \pm 1.10$ \\
\hline Diethyl ether & 0.74 & $26.28 \pm 0.26$ & $32.93 \pm 0.06$ \\
\hline
\end{tabular}

${ }^{1}$ Each value shown is the mean value \pm standard deviation.

\section{Antioxidant activity}

The antioxidant activity of different plant extracts of $P$. nodosus is determined by use of methanol solution of DPPH reagent. DPPH method is used in the study of antioxidant effects of complex biological compounds and of their ability to reduce the free radicals' activity. Activity is measured as a decrease in absorbance of the sample relative to the standard solution of DPPH. This research of $P$. nodosus extracts has not been investigated until now.

The results expressed in the form of $\mathrm{IC}_{50}$ values are shown in Table 2. Antioxidative efficiency was in the range from 641.77 to $8811.63 \mu \mathrm{g} / \mathrm{ml}$. The ethanol extract with the $\mathrm{IC}_{50}$ value at $641.77 \mu \mathrm{g} / \mathrm{ml}$ showed the most active reaction. Antioxidant activity index (AAI) is a number that indicates the success of a compound in the effects of antioxidation. The tested extracts showed weak antioxidant activity $(\mathrm{AAI}<0.5)$, while the control substance, as expected, showed a very strong antioxidant activity $(\mathrm{AAI}>2)$. 


\section{Antibacterial activity}

The results of in vitro antibacterial activities of acetone, ethanol, ethyl acetate and diethyl ether extracts of $P$. nodosus are shown in Table 3. For comparison, the tables also give the results of the activities of doxycycline. The solvent (10\% DMSO) had no effect on the growth of the tested microorganisms. Antimicrobial activities of tested extracts were assessed by determining the MIC and MBC values of these species of microorganisms.

Table 2. Antioxidant activity of the extracts from P. nodosus ( $\mathrm{IC}_{50}$ and AAI).

\begin{tabular}{ccc}
\hline Type of extract & $\mathbf{I C}_{\mathbf{5 0 v a l u e}}\left(\boldsymbol{\mu}_{\mathbf{g} / \mathbf{m l})}{ }^{1}\right.$ & AAI value \\
\hline Ethanol & $641.77 \pm 7.12$ & 0.13 \\
Acetone & $1066.61 \pm 128.99$ & 0.08 \\
Ethyl acetate & $8811.63 \pm 46.48$ & 0.01 \\
Diethyl ether & $1016.26 \pm 12.49$ & 0.08 \\
Ascorbic acid & 5.25 & 15.24 \\
\hline
\end{tabular}

${ }^{1}$ Each value shown is the mean value \pm standard deviation.

Table 3. Antibacterial activity of extracts from P. nodosus.

\begin{tabular}{lcccccccccc}
\hline & \multicolumn{2}{c}{$\begin{array}{c}\text { Ethanol } \\
\text { extract }\end{array}$} & \multicolumn{2}{c}{$\begin{array}{c}\text { Acetone } \\
\text { extract }\end{array}$} & \multicolumn{2}{c}{ Ethyl-acetate } & \multicolumn{2}{c}{ Diethyl } & \multicolumn{2}{c}{ extract } \\
Species & MIC $^{1}$ & MBC $^{2}$ & MIC & MBC & MIC & MBC & MIC & MBC & MIC & MBC \\
\hline$P$. aeruginosa & $>5$ & $>5$ & 5 & $>5$ & $>5$ & $>5$ & 5 & $>5$ & 250 & $>250$ \\
$\begin{array}{l}P . \text { aeruginosa } \\
\text { ATCC 27853 }\end{array}$ & $>5$ & $>5$ & 5 & $>5$ & $>5$ & $>5$ & 5 & $>5$ & 62.5 & 125 \\
\hline
\end{tabular}

${ }^{1} \mathrm{MIC}$ values for plant extracts are given as $\mathrm{mg} / \mathrm{ml}$, for antibiotic as $\mu \mathrm{g} / \mathrm{ml}$ - means inhibitory activity. ${ }^{2} \mathrm{MBC}$ values for plant extracts are given as $\mathrm{mg} / \mathrm{ml}$, for antibiotic as $\mu \mathrm{g} / \mathrm{ml}$ - means bactericidal activity.

The values of minimum inhibitory concentrations and minimum bactericidal concentrations obtained in this experiment were $5 \mathrm{mg} / \mathrm{ml}$ and $>5 \mathrm{mg} / \mathrm{ml}$. Efficacy of antibacterial activity depended on both the type of extract and the strains of tested bacteria. Among the tested extracts, the diethyl ether and acetone showed the greatest inhibitory effects against the tested bacteria, although the overall effectiveness was weak. Extractives from ethanol extract of P. nodosus did not inhibit Pseudomonas aeruginosa according to ALAM et al. (1999).

\section{Antibiofilm activity}

The results of in vitro antibiofilm activity of acetone, ethanol, ethyl acetate and diethyl ether extract of $P$. nodosus are presented in Table 4. The bacteria used in this part of investigation have been selected as the bacteria used for antibacterial activity with their biofilm formation potential.

The influence on biofilm formation varied among the tested strains and between the extracts. Both strains formed thick biofilm (strong producers). Completely different than the results for planktonic bacterial cells (MIC and MBC), the best results against biofilm had ethanol and ethyl acetate extracts. It is obvious that bacterial cells inside the biofilm are different and act differently than the free floating bacteria, which is already known (DoNLAN, 2002). The BIC 
values varied from 2.03 to $>10 \mathrm{mg} / \mathrm{ml}$. Antibiofilm properties of $P$. nodosus extracts of any kind have not been investigated before this evaluation.

Table 4. Antibiofilm activity of extracts from P. nodosus.

\begin{tabular}{lcccccccc}
\hline & \multicolumn{2}{c}{$\begin{array}{c}\text { Ethanol } \\
\text { extract }\end{array}$} & \multicolumn{2}{c}{ Acetone extract } & \multicolumn{2}{c}{$\begin{array}{c}\text { Ethyl acetate } \\
\text { extract }\end{array}$} & \multicolumn{2}{c}{$\begin{array}{c}\text { Petroleum } \\
\text { ether extract }\end{array}$} \\
Species & $\mathbf{B I C}_{\mathbf{5 0}}{ }^{\mathbf{1}}$ & $\mathbf{B I C}_{\mathbf{9 0}}{ }^{2}$ & $\mathbf{B I C}_{\mathbf{5 0}}$ & $\mathbf{B I C}_{\mathbf{9 0}}$ & $\mathbf{B I C}_{\mathbf{5 0}}$ & $\mathbf{B I C}_{\mathbf{9 0}}$ & $\mathbf{B I C}_{\mathbf{5 0}}$ & $\mathbf{B I C}_{\mathbf{9 0}}$ \\
\hline$P$. aeruginosa & 2.03 & $>10$ & 3.32 & 6.3 & 4.79 & $>10$ & 4.53 & $>10$ \\
$\begin{array}{l}P \text {. aeruginosa } \\
\text { ATCC 27853 }\end{array}$ & 9.75 & $>10$ & $>10$ & $>10$ & 7.95 & $>10$ & $>10$ & $>10$ \\
\hline
\end{tabular}

${ }^{1} \mathrm{BIC}_{50}$ values for plant extracts are given as $\mathrm{mg} / \mathrm{ml}$ - means $50 \%$ inhibitory activity.

${ }^{2} \mathrm{BIC}_{90}$ values for plant extracts are given as $\mathrm{mg} / \mathrm{ml}$ - means $90 \%$ inhibitory activity.

\section{CONCLUSION}

P. nodosus was extracted by four different solvents. Extracts have shown various results in phytochemical analysis. The highest total phenol content was found in the ethyl acetate extract (28.45 $\mathrm{mg} \mathrm{GA} / \mathrm{g}$ ) while the lowest content was in the ethanol extract (22.74 $\mathrm{mg} \mathrm{GA} / \mathrm{g})$, and the similar case was with the total flavonoid content. Antioxidative efficiency was in the range from 641.77 to $8811.63 \mu \mathrm{g} / \mathrm{ml}$. The ethanol extract with the $\mathrm{IC}_{50}$ value at $641.77 \mu \mathrm{g} / \mathrm{ml}$ showed the most active reaction. Antibacterial potential of extracts was weak, as well as antibiofilm potential, but $50 \%$ biofilm inhibitory concentrations were prominent. Altogether P. nodosus extracts should be investigated further.

\section{Acknowledgement}

This investigation was supported by the Ministry of Education and Science of the Republic of Serbia, grants No. III41010 and OI173032.

\section{References:}

[1] Alam, Z., Mostaqul HuQ, M., Jabbar, A., Hasan, M. (1999): Potamogeton nodosus: an aquatic source for bioactive compounds. Fitoter., 70 (5): 523-525.

[2] ANDREWS, J.M. (2005): BSAC standardized disc susceptibility testing method (version 4). J. Antimicrob. Chemother. 56: 60-76.

[3] Chaieb, K., Kouidhi, B., Jrah, H., Mahdouani, K., BaKhrouf, A. (2011): Antibacterial activity of thymoquinone, an active principle of Nigella sativa and its potency to prevent bacterial biofilm formation. BMC Complement. Altern. Med. 11: 29

[4] Donlan, R.M. (2002): Biofilms: microbial life on surfaces. Emerg. Infect. Dis. 8: 881890.

[5] Josifović M. eds (1975): "Flora of SR Serbia", Vol. VII, page 482-483, SANU, "Scientific work", Beograd 
[6] LES D., SHERIDAN D. (1990). Biochemical heterophylly and flavonoid evolution in north American Potamogeton (Potamogetonaceae). Amer. J. Bot. 77: 453-465.

[7] O'Toole, G.A., Kolter, R. (1998): Initiation of biofilm formation in Pseudomonas fluorescens WCS365 proceeds via multiple, convergent signalling pathways: a genetic analysis. Mol. Microbiol. 28: 449-461.

[8] Qais N., Mandal M. R., Rashid M. A., Jabbar A., Koshino H., Nagasawa K., Nakata T. (1998). A Furanoid Labdane Diterpene from Potamogeton nodosus, J. of Natural Produc. 61: 156-157

[9] Quettier-Deleu, C., Gressier, B., Vasseur, J., Dine, T., Brunet, C., LuyckX, M. (2000). Phenolic compounds and antioxidant activities of buckwheat (Fagopyrum esculentum Moench) hulls and flour. J. of Ethnopharmacol. 72: 35-42.

[10] SARKer, S. D., NAHAR, L., KumARASAmy, Y. (2007). Microtitre plate-based antibacterial assay incorporating resazurin as an indicator of cell growth, and its application in the in vitro antibacterial screening of phytochemicals. Methods 42: 321-324.

[11] Stepanović, S., Vuković, D., Dakić, I., Savić, B., Švabić-Vlahović, M. (2000): A modified microtiter-plate test for quantification of staphylococcal biofilm formation. $J$. Microbiol. Methods 40: 175-179.

[12] Takao, T., Kitatani, F., Watanabe, N., Yagi, A., Sakata, K. (1994). A simple screening method for antioxidants and isolation of several antioxidants produced by marine bacteria from fish and shellfish. Bioscience, Biotechnology, and Biochemistry 58: 17801783.

[13] THIERS, B. (2013). Index Herbariorum: A global directory of public herbaria and associated staff. New York Botanical Garden's Virtual Herbarium. Available from http://sweetgum.nybg.org/ih/ (accessed 28 April 2013).

[14] Wootton-Beard, P. C., Moran, A., Ryan, L. (2011). Stability of the total antioxidant capacity and total polyphenol content of 23 commercially available vegetable juices before and after in vitro digestion measured by FRAP, DPPH, ABTS and Folin-Ciocalteu methods. Food Resear. Internation. 44: 217-224. 